\title{
ISSUES AND AGENDAS
}

\section{Re-Entering Modernity: From The 'End of History' To 'The New World Order'}

\author{
TERRI KORECK \\ SAN DIEGO, CALIFORNIA
}

Silence begins in the channels of communication. Certain political leaders, institutions, and priests attempt to denounce what is happening, but are unable to establish contact with the population. The silence begins with a strong odor. People sniff the suicides [the deaths], but it eludes them. Then silence finds another ally: solitude. People fear suicides [deaths] as they fear madmen [read Hussein and Bush]. And the person who wants to fight senses his [her] solitude and is frightened.

Whereupon the silence reverts to patriotism. Fear finds its great moral revelation in patriotism, with its indubitable capacity for justification, its climate of glory and sacrifice (Jacobo Timerman 1982: 52). ${ }^{2}$

Why does violence become the erotic expression of a nation?

Haven't we all been frightened - from Tel Aviv to Los Angeles, from Madrid to Baghdad - this past week? Haven't we all seen people running for their gas masks in Tel Aviv, but also oddly enough in the United States? (The latter footage, courtesy of CNN - Cable News Network.) Now, we need to fight the fear, the silence, the solitude! Now, we must stop the ongoing process of creation of a space of solitude and fear here 'at home', in our lives.

Today is only January 21,1991 . I say only because the Pentagon production 'The Gulf War' has barely begun. Every time we turned on our TV screens over the past few days we have been complicit in the most insidious and disturbing social experiment orchestrated since the Third Reich. The war we have been 'watching', sadly, has barely begun. Thus far we have only seen 'the movie' that precedes 'the war'. High-tech footage, including shots through cameras mounted on bombs ('gun camera footage' in official Pentagon jargon), the careful use of splicing, and remarkable slickness went into this most significant production. As I see it, 'the Gulf' front, which is now only a war front implicating Saudi Arabia, Kuwait and Iraq, will soon expand to include (implicitly or overtly) other borders - Turkey, Iran, Israel, Jordan. More significantly, is the existence of a war front 'at 
home', in the United States. Here, 'at home', the stakes are high: freedom of speech, freedom of expression, freedom of the press. Who is claiming to speak in the name of 'patriotism'? Who is claiming to speak for 'America', for 'her'? The stakes have never been higher. We are participating in the subversion of these taken-for-granted constitutional and civil rights. If we want to uphold them, now is the time to speak up.

Ironically, the struggle over the definition of the elusive ideals that 'America' embodies is also here, 'at home', and not in 'the Gulf, as some would like us to believe. Just recall that already three years ago Kuwaiti ships were 're-flagged' with the flag of the United States of America, while trillions of Kuwaiti-generated dollars keep in motion the economies of the United States and other Western European countries. $^{3}$

Furthermore, the complicity of the United States - through present and past administrations - in Saddam Hussein's efforts to control the Middle East, is well documented and cannot be ignored.${ }^{4}$ Yet, we are told that American troops are in the Gulf to ensure 'our' freedom, here, 'at home', and to ensure 'the American way of life'. How is it that American women and men are made to feel good about doing what they do - in this case wage a war - by embodying and making credible a certain definition of 'patriotism' and 'America'? How do these definitions legitimate what has been all along an immoral and illegitimate project? Do not be misled; this is, indeed, a time of momentous personal - and thus, political - decisions. We confront silence and fear in the guise of canned and censored information. We have been watching 'The Gulf War', the movie, before the unfolding of the war. The remarkable - and frightening - display of 'new age', high-tech weaponry has been accompanied all along by an even more remarkable experiment to control populations through high-tech visual special effects and video linkages. ${ }^{5}$

\section{ENTER 'THE GULF WAR' \\ a new [anti]American production released by the Pentagon}

It is ironic that 'post-modern' coverage is the cover-up (disguised as coverage) of this wholly 'modern' war. A 'modern' texture, if you will, which is evident both at home where at stake is, for instance, the definition of 'patriotism', and in 'the Gulf' where apparently 'national' borders and disputed 'natural' resources are up for grabs. It is ironic that this grand-narrative is subtly introduced on our TV screens via linkages of localities through high-tech global networks, the kind of coverage epitomized by CNN and simulated by other networks. For instance, a 'postmodern' visual effects show spliced by NBC technicians 
was aired during the national evening news on Sunday, January 20. This visual 'assemblage' consolidated previously unthinkable linkages between different symbolic registers. In a matter of a few minutes we were exposed to a frantic juxtaposition of spliced images, simulating a sequence of flashbacks, showing the explosion of an Iraqi Scud missile in Tel Aviv, an American Patriot missile in the sky of Saudi Arabia, selected footage of high-tech weaponry from the newly released film Flight of the Intruder, footage from a Marine recruitment film showing training exercises, and last, to 'contain' it all, a massive display of American flags waved by fans before the start of Sunday's football game between the L.A. Raiders and the Buffalo Bills at Rich stadium. NBC's anchor, Tom Brokaw, whose voice guided us through this 'pastiche', provided the required authoritative seal of legitimacy for this journalistic travesty.

It is also ironic that multiple voices selectively arranged and deployed re-introduce us to the subverted values of 'civilization', 'love', 'patriotism', 'freedom', 'peace', and 'war'. It is indeed terrifying that we learn - courtesy of Cable News Network (CNN), and its new patron, the Pentagon - that war becomes love if you simply allow yourself to die for your buddy (and not for 'your country', a claim made in the past), by throwing your body in the way of enemy grenades and fire. ${ }^{6}$ This revolting lesson was taught by a Marine commander preparing his soldiers to die in the Saudi desert, and it was brought to us (by CNN) in the evening of January 21. Was that preacher of war, qua love, in the guise of love, addressing his soldiers? Or, was he addressing us, here, 'at home'?

These are only a few of the most disturbing instances of this monumental experiment conducted through horrifying symbolic slippages - and orchestrated through endless chains of VCR's and videotapes around the world - in order to install and secure a 'new world order', a new symbolic terrain which is the apparent complement of an already proclaimed hegemonic 'global' economic order. The need to install this 'new world order', whereby forms of economic capital and domination become transposed onto symbolic registers, might plausibly account for the eagerness of the Bush administration to engage in a military war with Iraq, rather than to rely on economic sanctions (implemented to 'punish' Iraq for occupying Kuwait). We are told that this 'global' economic regime of capitalist interdependence operates internationally, not nationally, that it cuts across the boundaries of nation-states, and that it is 'personified' by transnational corporations. Is it far-fetched to speculate that the purveyors of 'global' interdependence might benefit from bringing to us a "postmodern' cover-up/coverage of organized violence?

How many of you 'watched', during the first weekend of this war, American soldiers 'watching' on their giant television screens the 
explosion of enemy missiles in the Saudi sky, as if 'watching' a football game? ${ }^{7}$ Once again, the event was brought to us, and to them, courtesy of CNN (Cable News Network). I am afraid that soon we will all be encouraged to 'Be team players, and die in the Gulf' by way of the special visual and sound effects provided by $\mathrm{CNN}$, our global network. We 'at home' like the U.S. soldiers in the Gulf, are certainly the intended audience for this 'three way' experiment. We are expected to passively 'watch' and actively absorb this insidious indoctrination, which prepares us through highly censored video images to consent to this war abroad and at home. We are expected to be passive recipients of this monstrosity; to keep 'scores' at home. We are expected to marvel at, and react with awe to this unprecedented showcase of a high-tech war arsenal unveiled as the latest embodiment of 'civilization', and a distinctly masculine 'rationality' and 'objectivity'. ${ }^{8}$ We are expected to actively consent to this slipagge and re-definition of meanings. This is the war on the home front. It is our struggle to challenge these re-definitions.

Those who venture into the streets and demand 'peace' are characterized as 'backward', nostalgic, and inarticulate remnants of the 1960s. 'Peace' is passé and 'backward', and we are urged - even intimidated - to join the 'new world order' of high tech warfare. After all, many of us already enjoy playing Nintendo video games at home $!^{9}$ It is no different, there are limited human casualties! Not only are we portrayed by the media as dislocated and marginal ('inoperative 60 s nostalgia') with respect to the present, but we are carefully constructed as the 'enemy within', together with many members of the ArabAmerican community who are suffering the unconscionable consequences of war hysteria. An example of the limited and selectively arranged television 'coverage' of what is portrayed as a dismayed 'minority', includes the deliberate juxtaposition of peace rallies in the United States with pro-Hussein rallies in Algeria. Furthermore, an unjustified war hysteria 'at home' is cultivated by media reports overstating the fact that the (always elusive) 'American public' is purchasing gas masks in unprecedented numbers, ${ }^{10}$ and according to a CNN segment broadcast on Saturday, January 19 , it is said (by whom?) that many concerned Americans are sealing their homes in preparation of some sort of chemical attack!

\section{ENTER THE 'NEW WORLD ORDER'}

Today it is already January 25,1991 . The world will never be the same as it was before January 16, 1991 - and this has nothing to do with the trendy instability supposedly founded on a "postmodern malaise'. On the contrary, we have been reassured by the Pentagon that everything, including the military operations in the Gulf, is 'right 
on schedule'. Over the skies of Tel Aviv and Riyadh, the duel between American 'Patriots' and Iraqi 'Scuds' continues. Somewhere, someone keeps 'scores'. We 'watch' horrifying scenes of what might be the worst oil spill in history, courtesy of Saddam Hussein and George Bush. The most potent embodiment of destruction in our television screens is an oil covered cormorant - supposedly shown to restore some humanity in our lives by making up for the absence of images showing shattered and dismembered human bodies. Mr. Bush has accused Hussein of irrational behavior, implicitly claiming himself to be the embodiment of a rational plan for a 'new world order'.

So far, this so-called 'new world order' has been the only undefined term of the equation, redolent as it is with painfully taunting historical meanings. Today it is January 26, 1991. The meaning of the 'new world order' is now questioned and dismantled on a few radio stations. KPFK Pacifica station and, in the wee hours of the morning, the otherwise pro-war KPBS National Public Radio, have begun to ponder what this 'new world order' might be all about. ${ }^{11}$ These days, journalistic anxiety over the meaning of the term has resulted in a deluge of competing genealogies, all of which consciously seem to avoid linking it to Nazi sloganeering, while seeking to affix to it a myriad of alternative significations. Nevertheless, a certain and fixed significance is still very much absent at this time. This is where ironies stop and fear sinks in.

I fear that the meaning of 'the new world order' is not subject to contestation but indeed is historically overdetermined. After all, the producers of 'The Gulf War' - the Pentagon and its associates - are confidently relying on the already decreed 'end of History' articulated over a year ago by $F$. Fukuyama, a then pseudo-intellectual employee of the State Department. ${ }^{12}$ The dictum 'end of History' was brought to us as an interpretive exercise meant to fix the meaning of the collapse of the 'Berlin Wall', its ramifications throughout Eastern Europe, and beyond, and its historical resonances. If anything, this ideological exercise affected the required transposition of the power to dominate and objectify the 'way things are or must be' from an 'economic' register, epitomized by a dominant worldwide capitalist system, to a 'symbolic' register. Supposedly, the transposition vested the symbolic power to re-define 'the new world order' in the United States of America, which had presided over the end of the Cold War. It is time to reject 'the end of history'.

Mr. Bush admonished all of us during his Thanksgiving tour of the Persian Gulf that the 'Desert Shield Operation' (now 'Desert Storm') was not going to be 'another Vietnam', asserting 'This time we are going to win'. ${ }^{13} \mathrm{Mr}$. Bush is correct. No, this is not another Vietnam. It is my conviction and that of many, many others that this is not another Vietnam because history has not come to end, and everything 
is still subject to contestation. It seems to me that several miscalculations were made in the name of 'the end of History'. Central among them is the expectation on the part of the Bush administration, and the supporters of its policies in the Middle East, that the only forms of contestation and resistance available to war protesters in the United States are necessarily linked to the peace movement during the Vietnam war. History has not come to an end, and the present opposition to 'Operation Desert Storm' has the potential to envision a different sort of 'America', to articulate an alternative standpoint here, 'at home'. The large 'coalitions' and 'alliances' for peace rallying throughout the United States aim to reclaim and redefine the meaning of 'America', of 'patriotism', and 'peace'. It is all these meanings that are the subject of contestation, not in the Gulf, but here, 'at home'. Nothing clinches this process better than the amazing sight of both pro-peace and pro-war demonstrators carrying American flags and voicing the common theme, 'Support the Troops'.

Like the ex-Argentinian journalist Jacobo Timerman who was 'dissapeared', and as a Jew, emasculated, feminized, and tortured, and later stripped of his Argentine citizenship at the moment of his release, we must too fight against fear, and denounce the pernicious effects of silence which are masking a 'dirty war'. We cannot let fear and silence, which are the metaphoric equivalents of 'the end of history', define 'the new world order'.

\section{The Gulf War (Part II) or 'The Father of All Parades' June 1991}

And above all, it frightens me that everything I am saying has already been said. That it has even been explained $[. .$.$] What is frightening is to realize how content we feel$ because we suppose there are deeds that cannot be repeated.

(Jacobo Timerman 1982: 134)

Since hostilities between the allied forces led by the United States and Iraq ended on February 28, 1991, the contours of the 'new world order' have begun to emerge at home and abroad. Visiting Iraq in March, the United Nations under-secretary reported that the country had been bombed back to a 'preindustrial' age. Moreover, at least 6,700 Iraqis, most of them Kurds, died in Turkish refugee camps near the border, adding to the hundreds of thousands of Iraqi casualties inflicted by the allied forces during the armed conflict. 'A World on the Move' read the headlines of a New York Times article (published in mid June) describing the conditions of the five million refugees displaced in the Gulf War. The 'new world order' is marked by the 'globalization' (of unprecedented scope) of human suffering and ecological disaster.

Meanwhile, on the main streets of the United States, a Pentagon's Joint Task Force 'Victory', in charge of operating telephone systems and analyzing computer printouts and flow charts, orchestrated and 
managed an endless succession of military parades. The last spectacle, staged in New York City on June 10, was described by Mayor Dinkins as the 'Mother of All Parades' - although 'the Father of All Parades' would have been a more apt description for that festival of militarism. A few days earlier the biggest victory celebration since the end of World War II had been staged in Washington DC. Unprecedented was the most impressive display of weapons and war technology in recent US history: for two hours processions of troops, tanks, missiles, helicopters, jets, boats, artillery, armored trucks, and even unmanned reconnaissance aircraft, paraded down Constitution Avenue. We 'watched' others 'watching' through the live television coverage of the celebrations.

Here 'at home' this impressive display of military technology coincides with increasingly powerful police forces, and a frightening erosion of the right of free speech. Ironically, the formal end of hostilities abroad marked the continuation of the steady reversal of certain constitutionally protected activities at home. For example, some of the most disturbing Supreme Court rulings were produced over the last few months. At home, the 'new world order' represents diminishing freedoms. The Supreme Court voted to allow forced or coerced confessions to be admitted as evidence in legal proceedings; another ruling broadens the powers of the police by legalizing mass searches on trains and buses. But the epitome of all 'silencing' is the Supreme Court's decision forbidding abortion counseling at clinics receiving federal funding, even when patients specifically ask for information or referrals. The Court ruled 5 to 4 that doctors do not have a free speech right to inform patients of their medical options. This ruling also effectively denies low-income women the information to which they are legally entitled. Are these the 'old' ground rules for the post Cold War era?

\section{Acknowledgements}

I dedicate this piece to Maria Cristina Prado. In Argentina, together we learned the pernicious effects of 'silence'. I thank Jennifer Robertson for her encouragement, support, and editorial comments.

\section{Notes}

1 Parts of this essay were written between January 21 and January 25, 1991. The diary-like quality of those reflections has been left untouched. The essay is intended as a thought provoking piece, and not as a comprehensive account of 'the Gulf War', a historical juncture which is as complex as it is troublesome.

${ }^{2}$ Jacobo Timerman was the editor and publisher of the Argentine newspaper La Opinion from 1971 until his arrest by military authorities on April 15, 1977. Released in September 1979, he lived in Tel Aviv, Madrid, and New York. 
${ }^{3}$ Santa Barbara News Press, January 13, 1991.

${ }^{4}$ Village Voice, December 18, 1990.

${ }^{5}$ The mass media has certainly stressed the former while trivializing the latter as war propaganda, without ever suggesting that this represents the significant and consequential use of a technology of domination. 'Smart' weapons are certainly the object of overwhelming public ovation and media celebration; see for example Los Angeles Times, January 21, 1991.

${ }^{6}$ What all this underscores is the extent to which the now familiar argument that 'nations are imagined communities' (Anderson 1983 among others) is made, remade, and unmade at times of war. In this connection, it is interesting to note that the polished black granite walls of the Vietnam Veterans Memorial in Washington, DC, contains the names of 58,000-plus Vietnam casualties not in alphabetic order, but by date of death or disappearance to ensure that buddies can stay together. This possibly alludes to the 'fragility' and precarious existence of an all-encompassing national imagination, a 'community in anonymity'.

${ }_{7}$ The resonances are not accidental. For example, a Los Angeles Times reporter chose to describe the Sunday football game between Raiders and Bills in now familiar terms: This most American of pageants stood for something. Defiance, maybe. Resolve. Patriotism, even. Like poking a stick in Saddam Hussein's eye'. (Los Angeles Times, January 21, 1991).

${ }^{8}$ See the insightful essay 'Sex and Death in the Rational World of Defense Intellectuals' by Carol Cohn (Signs, 12 (4), Summer 1987).

${ }^{9}$ This was pointed out in an insightful commentary by Howard Rosenberg ('TV's Other Battle: Suits vs. Screamers') published in the Los Angeles Times, January 19, 1991.

${ }^{10}$ Los Angeles Times, January 24, 1991.

"See also The New York Times, January 20, 1991.

${ }^{12}$ See F. Fukuyama, 'The End of History', National Interest, (16) 1989. Of related interest: On 'the end of history', The New York Times Magazine, 22 October 1989; also on 'endism', Harper's magazine, November 1989.

${ }^{13}$ Los Angeles Times, January 20, 1991 . Additional interpretations of $\mathrm{Mr}$. Bush's statement suggest that media coverage of the Vietnam war contributed to the growing anti-war movement in the United States at the time (see Los Angeles Times, January 21, 1991). Pentagon censored/"cleared' information is the current response to the 'Vietnam lesson'. Furthermore, it seems to me that we are also participating in a complete redefinition of what counts as 'information', and not simply in a campaign to censor it or protect it, but maybe even to make up whole stories, and 'stage' TV 'coverages'.

Editorial Note Readers may wish to know of: (1) 'Watching the War' Women's Review of Books 7(10-11) July 1991, 4-13 which comprises seven diaries, letters, essays. (2) C.D.B. Bryan 'How Desert Norm Learned to Win' Reader's Digest ('World's most read magazine: 28 million copies - 15 languages. British edition...) June 1991, 28-32. 